\title{
Competition for feeding in waders: a case study in an estuary of south temperate Europe (Mondego, Portugal)
}

\author{
Tiago Múrias Santos ${ }^{1}$, , João Alexandre Cabral ${ }^{2}$, Ricardo Jorge Lopes ${ }^{1}$, Miguel Pardal ${ }^{3}$, \\ João Carlos Marques ${ }^{3} \&$ John Goss-Custard ${ }^{4}$ \\ ${ }^{1}$ CIBIO-UP, Campus Agrário de Vairão, 4485-661 Vairão, Portugal \\ ${ }^{2}$ CETAV, Laboratório de Ecologia Aplicada, Departamento de Ciências Biológicas e Ambientais, Universidade de \\ Trás-os-Montes e Alto Douro, 5009-911 Vila Real, Portugal \\ ${ }^{3}$ IMAR - CIC, Universidade de Coimbra, 3004-517 Coimbra, Portugal \\ ${ }^{4}$ CEH - Winfrith Technology Centre, Dorchester, Dorset DT2 8ZD, United Kingdom \\ (*Author for correspondence: Tel.: +351-223401497, Fax: +351-223401511,E-mail: tdsantos@fc.up.pt)
}

Received 16 May 2003; in revised form 15 December 2004; accepted 12 January 2005

Key words: competition, feeding, waders, habitat loss, Portuguese estuary

\begin{abstract}
The loss of feeding areas may pose a threat to many wintering waders because increased competition arising from reduced foraging space may force birds either to emigrate or to die. This has been demonstrated to occur in northwest European estuaries, but virtually no studies have been performed in the estuaries of southern Europe, where the loss of supratidal habitats (salines and saltmarshes), rather than intertidal habitats, are currently the main threat to waders' habitats. If these habitats are lost, waders may be forced to move to the intertidal mudflats, perhaps increasing competition between individuals and ultimately leading to starvation or emigration. We tested this hypothesis in the Mondego estuary, a small estuary on Portugal's west coast, which is presently under heavy human pressure. We used indirect methods to test for the occurrence of both components of intra-specific competition: interference and prey depletion. We found no evidence that either interference or depletion competition was occurring at present, either on the mudflats or in the salines. Overall, the results suggest that the intertidal mudflats may still be able to accommodate birds displaced from the destroyed supratidal salines, but modelling is required to predict the effect that the combined loss of feeding area and foraging time that this would entail would have on their fitness, and thus numbers.
\end{abstract}

\section{Introduction}

The loss of feeding places in an estuary may pose a problem for the waders that usually feed there. While birds may eventually leave the area, it is expected that their first reaction would be to redistribute themselves within the estuary (GossCustard \& Durell, 1990). The immediate consequence of redistribution following habitat loss is an increase in the densities of birds feeding in those areas that remain (Goss-Custard \& Durell, 1990). As densities rise, competition between birds may increase, leading to a reduction in intake rate. At a certain point as competition intensifies, emigration and/or mortality rates also begin to increase, whereupon they become density-dependent. From this point on, further habitat loss or deterioration will increase emigration and/or mortality rates, and the population size will decrease (Goss-Custard \& Durell, 1990; Goss-Custard et al., 1996). As 
stressed by Goss-Custard \& West (1997), the moment at which this point is reached is what really matters as, when it is passed, it ultimately leads to a reduction in bird numbers.

In north European estuaries, the direct removal of intertidal areas for industrial and urban construction is reported as the major cause of habitat loss (Smit et al., 1987; Schekkerman et al., 1994). This seems not to be the case in the southern European estuaries, at least those on the Atlantic coast of Portugal. Here, habitat loss is mainly due to the destruction and/or conversion of supratidal habitats, such as artificial saltpans, or salines (e.g., Rufino \& Neves, 1992). Portuguese salines are usually regarded as mainly providing supplementary feeding over high-water, on the assumption that this habitat is less suitable than the mudflats for most waders, although this may depend on the species and/or the time of the year considered (Rufino et al., 1984; Múrias, et al., 1997, 2002; Luís, 1999; Lopes et al., 2001). In the Mondego estuary (western Portugal), for example, up to $42 \%$ of the total number of waders present can be found feeding in the salines at low-water, irrespective of the season, against some $70 \%$ at highwater (Múrias et al., 2002). The lack of winter management of this habitat also causes many ponds to be flooded from October to March, thus preventing their use by birds over that period (Múrias et al., 1997). Nevertheless, the salines may still play an important role by providing both extra feeding places and extra feeding time at low-water and at high-water (Múrias et al., 2002). Consequently, their loss may be detrimental to many species.

In the Mondego, as in other Portuguese estuaries, there have been increasing losses of salines over the last decade (Múrias, 1997; Lopes et al., 2001; Múrias et al., 2002). The effects, if any, that these losses may already have had on the waders of the Mondego estuary have not been monitored, however. This paper, therefore sets out to predict whether a continuing loss of salines would have an impact on the birds through intensifying competition. We do this by thinking of a scenario in which all existing salines have been rendered unusable by waders so that all birds in the estuary can only feed on the intertidal mudflats: other supratidal habitats (ricefields, fishfarms) are unsuitable for feeding or cannot be regularly used by waders (Múrias et al., 1997; Lopes et al., 2001). This scenario would affect the feeding conditions of the birds in two ways. It would remove feeding areas in the salines, thereby reducing the total quantity and area of food available to the birds over low-water. It would also remove a source of food that is used over high-water by birds that, over low-water, feed either in the salines or on the inter-tidal flats of the estuary itself. It would therefore reduce the amount of time available to all birds for feeding from its present level of $12.15 \mathrm{~h} /$ tidal cycle to ca. $8 \mathrm{~h} /$ tidal cycle; i.e., the time for which the intertidal mudflats are exposed.

In this study, we try to assess whether such reductions in food supply would make it more difficult for birds to survive the winter in good condition, because the birds on the mudflats are already subjected to intra-specific competition for food. It is already well-known that intra-specific competition can occur in wintering waders and can take two forms: (a) interference while feeding and (b) prey depletion, both of which can reduce intake rate (Goss-Custard, 1980). This paper is only concerned with testing whether either, or both, forms of competition occur in this particular system. If one or both forms of competition were to be detected in this system, one would expect further habitat loss to intensify it and perhaps lead to density-dependent reductions in overwinter survival rate and/or poorer body condition at the time of the spring migration (Goss-Custard \& Durell, 1990). This outcome would put in danger the longterm survival of wader populations in the Mondego estuary.

\section{Study area}

The Mondego estuary is located on the west coast of Portugal $\left(40^{\circ} 08^{\prime} \mathrm{N}, 8^{\circ} 50^{\prime} \mathrm{W}\right)$ and is presently about $7 \mathrm{~km}$ long by $2-3 \mathrm{~km}$ wide. During the main study period (1993-1995), it comprised a total area of wetland habitat of approximately 1131 ha (Múrias et al., 1997). In the seaward part, the river divides into two arms surrounding an alluvialformed non-tidal island, the Morraceira (Fig. 1). Of the total area of wetlands available for waders, only 134 ha $(11.8 \%)$ were intertidal. The remainder consisted of saltmarshes $(5.5 \%)$ and humanmade or modified supra-tidal habitats: salines 


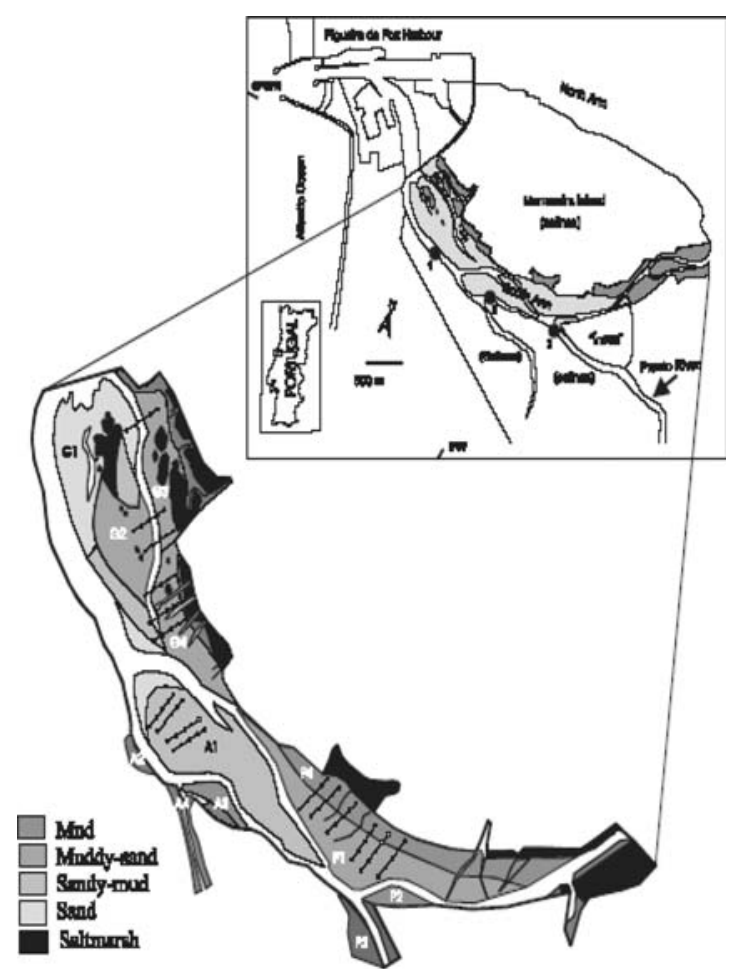

Figure 1. The study area in the south arm of the Mondego estuary, showing the sediment types and the 12 census sub-areas that were combined to form the three main areas, 'Gala' $(\mathrm{G})$, 'Armazéns' (A) and 'Pranto' (P). The three points from which the birds were counted $(1,2,3)$ in the south arm are also shown, along with the 16 transects used for the invertebrate sampling.

(27\%), fish-farms (17\%) and channels (38.7\%) (Múrias et al., 1997). From 1996 to 2001, an additional 96 ha of mud and sandflats were created in the north arm, as a consequence of dredging works associated with the enlargement of the Figueira da Foz harbour (Lopes et al., 2001). However, the percentage of birds of the studied species that used these areas was only $6-14 \%$, so they were not included in the calculations.

The mudflats and salines are the main lowwater feeding areas in the estuary. The channels sometimes provide low-water feeding sites, but they are mostly used during the autumn migration period. At high-water, most birds move to the salines where many continue feeding (Múrias et al., 1997; Lopes et al., 2001). Ricefields and fishfarms may also be used through the whole tidal cycle as feeding areas. However, their use is constrained by their management regime. The ricefields are used only in spring and by a limited range of species, whereas the fishfarms are used in those brief periods, usually in autumn, when they are emptied for maintenance (Múrias, 1997).

Despite the small area of the intertidal mudflats, there was an appreciable variation in the type of sediment present. The flats adjacent to the margins of the south arm of the Morraceira island were made-up of finer sediments, while the central banks consisted mainly of coarse-grained sediments (sand or muddy-sand) (Cunha \& Dinis, 2002). Based on these differences in the sediment composition, it was possible to subdivide the estuary into 12 discrete sub-areas (Fig. 1), naturally delimited by channels and creeks. The average size of these areas was $10.02 \pm 11.8$ (SD) ha (range: 0.7-27.1 ha). A dense Spartina spp. marsh was present alongside the island, with sparse meadows occurring downstream. The duration of the exposure time in different parts of the intertidal zone varied by only 0.5 $-1 \mathrm{~h}$ on an average high-tide of $0.8 \mathrm{~m}$.

The salines were in the Morraceira Island and along the left bank of the south arm, and all were of the traditional type. A typical saline in the Mondego is formed by a set of small ponds (storage, evaporation and preparation ponds) of decreasing depth $(20 \mathrm{~cm}$ to $2-3 \mathrm{~cm})$ and increasing salinity, connected by drainage channels and sluices and linked to the river through a reservoir 80 $\mathrm{cm}$ deep (Múrias et al., 2002). The average area of a saline in this estuary is 4.0 ha. Storage and evaporation ponds were the preferred feeding places for waders (Múrias, 1997).

\section{Methods}

\section{Field methods}

The study was restricted to the three species most likely to be affected by competition due to their high abundance and widespread distribution: Kentish Plover Charadrius alexandrinus, Ringed Plover Charadrius hiaticula and Dunlin Calidris alpina.

\section{Interference competition}

Following the logic of Goss-Custard et al. (1982), we predicted that, if interference competition was 
acting in this system, the proportion of the total estuary population that fed in a preferred habitat over low-water would decline as total numbers increased. With few competitors present, all the birds could feed in the most preferred sites without too much interference. But as the total numbers increase, interference would intensify, eventually making it more profitable for some birds to move to other less preferred sites within the estuary. The competition hypothesis might also predict that, as the total number of birds in the estuary increases, an increasing proportion would be forced to feed in the salines over high-water. This is because increased competition over low-water would make it more difficult for some birds to get all the food they need when the tidal flats are exposed, and so they continue to feed at high-water. Censuses, therefore, provided the main data with which to test for the presence of interference competition.

The number of each species feeding in each of the 12 sub-areas of the estuary mudflats and a large sample of 39 salines $(90.6 \%$ of the total number) in the Morraceira island, were counted 12 times a month with $10 \times 50$ binoculars and a 20 $60 \times 50$ telescope. For the mudflats, counts were made from three fixed positions along the south arm (Fig. 1). In the salines, a car was used to follow a fixed route. All counts were made within $2 \mathrm{~h}$ of dead water on spring tides. A total of 102 counts in the south arm mudflats and in the salines at low water, and 12 counts in the salines at high water, were available for the period 1993-2000. To test for the occurrence of interference competition up to 33 counts at low water in the build-up phase (July-December) for the years 1993-1994 and 1996-2000, and 12 counts at high-water for the same months, for 1993-1994, were used. Additionally, 7 winter counts (late November-March) from 1993-1994 were used in the study of prey depletion.

All waders seen on the mudflats were counted and the boundaries of their flocks plotted on a map, drawn from aerial photographs. The birds present in the salines were counted next day. It was assumed that all the birds present fed in the areas where they were observed, even if they were not feeding at the time they were counted. The maps of bird flocks were superimposed on the map of the sub-areas, allowing the allocation of each flock (or part of it) to a given sub-area. Whenever a flock was spread over several sub-areas, bird numbers were assigned to each sub-area in proportion to the respective area occupied by the flock. Counts were obtained this way for each sub-area but, in the final analysis, they were combined to form three main areas, named 'Gala', 'Armazéns' and 'Pranto'.

\section{Depletion}

Due to logistic constraints, it was not possible to sample all the 12 sub-areas to measure the overwinter rates of prey depletion. In October 1994, a series of transects were marked out in each of the three main feeding areas (six transacts were placed in 'Gala', four in 'Armazéns' and six in 'Pranto'). Each transect in areas 'Gala' and 'Pranto' contained five regularly spaced sampling points, marked with bamboo stakes (Fig. 1). In area 'Armazéns', due to characteristics of the terrain, the four transects from downstream to upstream had, respectively, 5, 11, 18 and 6 sampling points. A total of 90 sampling points were used. In late November and early March, one sample was taken at each sampling point in each transect using a core of $95 \mathrm{~cm}^{2}$ in area and $5 \mathrm{~cm}$ deep. The samples were taken to the laboratory, washed and sieved through a $0.5 \mathrm{~mm}$ mesh, and stored in $4 \%$ neutralised formol. The collected organisms were later separated, preserved in 70\% alcohol and identified and counted under a binocular microscope.

The prey species selected were the mobile gastropod Hydrobia ulvae and several, mostly sedentary, small worms (polychaetes and oligochaetes). Due to their abundance in the estuary, the small polychaete species Alkmaria romijni (ex-Amage adspersa) and Streblospio shrubsolii were treated separately. Hydrobia were divided into two groups roughly corresponding to (i) the small, and presumably less profitable, size-classes $<1.5 \mathrm{~mm}$ in length, and (ii) the larger, and presumably more profitable, size-classes $>1.5 \mathrm{~mm}$ (Goss-Custard et al., 1991).

\section{Data analysis}

\section{Interference competition}

In order to test for the presence of interference, the proportion of each species in each particular 
habitat or area was regressed against the total number of birds in the estuary during the build-up phase (late July-December), when interference competition might be expected gradually to intensify (Goss-Custard et al., 1982). We considered both the intertidal areas and the salines as being potentially preferred areas where interference competition might occur. In fact, the salines had previously been considered as providing mostly supplementary feeding (Múrias, 1997; Múrias et al., 2002), but this assumption had never been formally tested.

Due to differences between areas in size, sediment composition and degree of disturbance by people, each of the three main intertidal areas was separately analysed. The analyses were performed for each species and area (salines and intertidal areas) at low-water, and for the salines at highwater.

As bird numbers increased steadily throughout the build-up phase, the total numbers on the estuary and the number of days elapsed since July 15th were closely correlated. This raises the possibility that different seasonal patterns of change in the food supply in the three areas could confound with bird numbers, thus making interpretation of the results difficult. However, the food supply in the three areas co-varied in parallel over the winter (see below), suggesting that the relative quality of the three feeding areas would not have changed over the build-up phase. The collinearity of the total number of days elapsed is not regarded, therefore, as an hinderance to interpreting results.

Disturbance of birds by people is frequent on the intertidal flats (e.g., Davidson \& Rothwell, 1993) and perhaps on the salines. In the Mondego estuary, significant disturbance by people - baitdiggers - was only observed in the intertidal area 'Gala'. To test for a possible effect of disturbance on bird distribution, the numbers of birds in 'Gala' were regressed against the number of people present during the build-up phase. If birds had been disturbed away from the Gala by people, a negative relationship should be present. Numbers were not influenced by human disturbance in any of the three species studied $\left(F_{1,25}=0.88\right.$, $F_{1,28}=0.001, F_{1,28}=0.66$, ns; for Kentish Plover, Ringed Plover and Dunlin, respectively), suggesting that bird distribution at the spatial scale considered was unaffected by the presence of people.
In order to conform with the assumptions of the parametric tests, proportions were transformed $(\arcsin \sqrt{n})$. The counts using the birds in salines at high-water excluded those birds that were also present in the salines over low-tide (i.e throughout the tidal cycle), as well as those birds that were roosting at high-tide. In this way, we were able only to consider the birds that had fed over lowwater on the mudflats but then continued feeding over high-water in the salines.

\section{Depletion}

In addition to the interference competition, food depletion over the winter could also lead to competition between birds due to a reduction in the standing crop of the food supply. As no recruitment and little growth usually occurs over the winter in most northern-temperate estuaries (McLusky, 1989), the invertebrate food resources of shorebirds there usually decline from autumn to spring through depletion by waders and other predators and through a variety of other causes of loss (e.g., gales). If waders contribute a great deal to the prey loss, increased bird densities in an area will necessarily increase the rate of prey depletion, potentially decreasing intake rates and thus intensifying competition (Goss-Custard, 1980). But in the Mondego estuary, as in many estuaries of southern Europe, recruitment and, particularly, growth continues in several species throughout the winter (Pardal, 1998; Cardoso et al., 2002; Dolbeth et al., 2003). Although winter growth of invertebrates in this estuary is much lower than its spring-summer equivalent (M. Pardal, personal communication) this could, nevertheless, prevent depletion by birds by reducing the standing crop of their food supply, so preventing competition through depletion from occurring.

We first investigated whether the standing crop biomass of the prey did decrease over the winter or whether it remained constant, or even increased, because prey losses from all sources were replaced by recruitment and growth. But to predict whether an increased density of waders would decrease their food supply over the winter, we also needed to know whether the birds currently removed a significant proportion of the standing crop. We therefore compared the total energy requirements of the birds over the winter with the prey standing crop at various stages throughout the winter. 
Overwinter prey loss. Whether the food supply was reduced over the winter was investigated by comparing the biomass of prey species (Table 1) in early winter (November), before the main arrival of wintering birds, with those in early spring (March), after most wintering birds had gone, but before the arrival of spring migrants. If prey abundance was reduced significantly, prey depletion could have been important because it would imply that prey losses were not replaced by recruitment and growth.

Total prey removed. The simple comparison of biomass at the start and end of winter, however, does include any effect of other non-shorebird predators on prey abundance. In order to provide a measure of depletion by the study birds themselves, we compared the total energy of the main prey available in the feeding areas across the winter with the energy requirements of all the birds. By using the monthly values for the prey standing stocks, the influence of prey growth and recruitment between two consecutive months was largely taken into account.

The total biomass of all the intertidal invertebrate species present at the start of winter was considered to be the food supply of the shorebirds. Data on the biomasses of invertebrates $\left(\mathrm{g} \mathrm{m}^{-2}\right)$ were obtained for the months of November 1993 through March 1994 (Pardal, 1998; Cardoso et al., 2004). We assumed that all prey size-classes were taken by waders. In fact, it is likely that, for some species/groups (e.g. Nereis (Hediste) diversicolor), only the larger size-classes were actually taken

Table 1. Contribution of each invertebrate taxa to the overall biomass (expressed in energy equivalents, $\mathrm{kJ} \mathrm{m}^{-2}$ ) present in the intertidal flats of the Mondego estuary, between November 1993 and March 1994

\begin{tabular}{lcc}
\hline & $\begin{array}{c}\text { Average monthly } \\
\text { biomass }( \pm \mathrm{SD})\end{array}$ & $\begin{array}{l}\text { \%Contribution to } \\
\text { total biomass }\end{array}$ \\
\hline Polychaeta & $14.18 \pm 9.39$ & 2.0 \\
Bivalvia & $110.23 \pm 45.86$ & 15.6 \\
Hydrobia ulvae & $521.46 \pm 73.43$ & 73.7 \\
Other Gastropoda & $18.01 \pm 9.63$ & 2.6 \\
Crustaceans & $49.08 \pm 23.81$ & 6.9 \\
Other & $1.19 \pm 1.18$ & 0.2 \\
All taxa & $707.22 \pm 89.47$ & 100.0 \\
\hline
\end{tabular}

(Pienkowski, 1982; Goss-Custard, 1984; GossCustard et al., 1991; Moreira, 1994a, b; Piersma, 1996). Therefore, our measures may have overestimated the energy available to shorebirds from these groups. These values, thus, provide a maximum measure of the total gross energy available to waders in the mudflats (Evans et al., 1979).

Although the diets of some wader species are still poorly studied in the Mondego estuary, Lopes et al. (1998) and Cabral et al. (1999) presented some data on the most numerous species: Dunlin, Ringed Plover, Kentish Plover and Grey Plover Pluvialis squatarola. According to these authors, these species feed mostly upon polychaetes (35-67\% occurrences in feacal pellets), Hydrobia ulvae (33-74\%), Scrobicularia plana (2.9-22\%) and small crustaceans (11-44\%). Two other important wader species using the estuary in winter are the Black-tailed Godwit Limosa limosa and the Avocet Recurvirostra avosetta. Unfortunately, there are no dietary data available for these species. We have assumed that godwits preyed mostly upon bivalves (Scrobicularia plana), and Avocets ate mostly polychaetes, as they do in the Tagus estuary (Moreira, 1994b; 1995).

The Total Gross Biomass (TGB) of invertebrates present in a month per unit area $\left(\mathrm{g} \mathrm{AFDM} \mathrm{m}{ }^{-2}\right.$ ) was calculated as

$$
\mathrm{TGB}=\Sigma \mathrm{B}_{i j}
$$

where $\mathrm{B}_{i j}$ is the average biomass density $\left(\mathrm{g} \mathrm{AFDM} \mathrm{m}{ }^{-2}\right.$ ) of the $i t h$ intertidal invertebrate species, according to the data obtained from Pardal (1998) and Cardoso et al. (2004), in month $j$. The Total Gross Energy (TGE) present on a given month per unit of area $\left(\mathrm{kJ} \mathrm{m}^{-2}\right)$ was then calculated as:

$$
\mathrm{TGB}=\Sigma\left(\mathrm{B}_{i j} \times 21\right)
$$

where 21 represents the average calorific value of $1 \mathrm{~g}$ of ash-free dry weight (McLusky, 1989; Zwarts \& Wanink, 1993)

The gross energy requirements of each bird species were calculated from the total bird-days present in each month, as calculated from the winter counts for November-March 1993-1994 (see Field methods). The Total Gross Biomass Consumed (TGBC), in $\mathrm{kJ} \mathrm{m}^{-2}$ month for each species was calculated as: 


$$
\mathrm{TGBC}=\mathrm{BD} \times \text { gross } \mathrm{FMR} \backslash 1,340,000
$$

where $\mathrm{BD}$, the number of bird-days, is $N$ (average number of birds per month) $\times 30$ days, and FMR is the Field Metabolic Rate, the gross energy daily expenditure of a bird involved in 'normal' activities (feeding, roosting, preening, flying). FMR was calculated using Nagy et al. (1999) equation for a range of species of Charadriiforms, using the double-labelled water method $\left(\mathrm{D}_{2} \mathrm{O}\right)$ : $\mathrm{FMR}=8.13 \times \mathrm{BM}^{0.77}$, expressed in $\mathrm{kJ}$ bird day ${ }^{-1}$. The value $1,340,000$ is the total area, in $\mathrm{m}^{2}$, of the intertidal mudflats. Body masses (BM) were obtained from Cramp \& Simmons (1983), using the appropriate values for the latitude and time of year (Table 2). TGBC values were divided by 0.80 to take assimilation efficiency into account (Klaassen et al., 1990).

\section{Results}

\section{Interference competition}

There was no evidence to suggest that interference competition occurred amongst birds feeding over

Table 2. Energy requirements (Total Gross Biomass consumed) of the wader species present in the winter of 19931994 on the Mondego estuary

\begin{tabular}{lccc}
\hline Species & $\begin{array}{c}\text { Body } \\
\text { weight } \\
(\mathrm{kg})\end{array}$ & $\begin{array}{l}\text { FMR } \\
\left(\mathrm{kJ} \mathrm{day}^{-1}\right)\end{array}$ & $\begin{array}{l}\text { Average } \\
\text { monthly } \\
\text { bird-days } \\
( \pm \mathrm{SD})\end{array}$ \\
\hline Kentish Plover & 50 & 93 & $2688 \pm 2690$ \\
Ringed Plover & 50 & 93 & $2568 \pm 1859$ \\
Grey Plover & 190 & 232 & $4320 \pm 1523$ \\
Numenius spp. ${ }^{1}$ & 560 & 484 & $138 \pm 137$ \\
Black-tail.Godwit & 290 & 309 & $3876 \pm 8617$ \\
Comm. Sandpiper & 50 & 93 & $156 \pm 130$ \\
Knot & 140 & 188 & $168 \pm 282$ \\
Dunlin & 50 & 93 & $16128 \pm 11596$ \\
Little Stint & 30 & 66 & $186 \pm 416$ \\
Avocet & 240 & 272 & $14802 \pm 8571$ \\
All species & & & $4053 \pm 6001$ \\
\hline
\end{tabular}

FMR is calculated from the bird body masses shown, using the allometric formulae of Nagy (1999) and assuming an assimilation efficiency of $80 \%$ (Klaassen et al., 1990).

${ }^{1}$ Numenius arquata and $N$. phaeopus. The values for these especies were averaged in all cases.

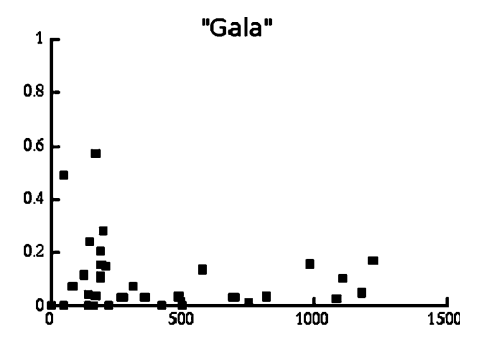

"Armazéns"

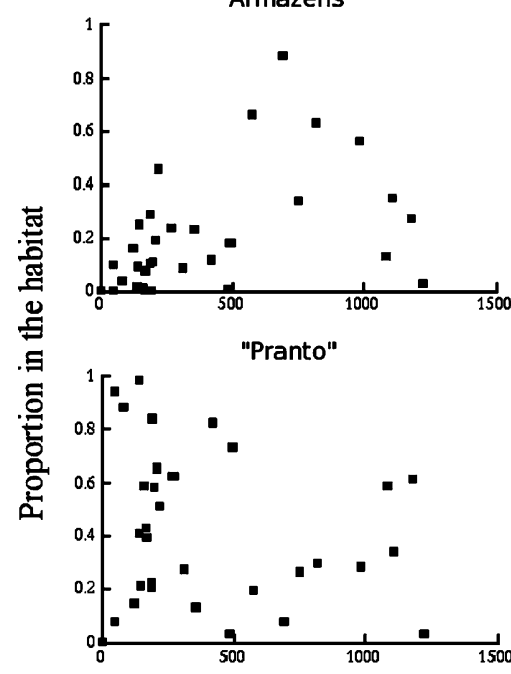

Salines

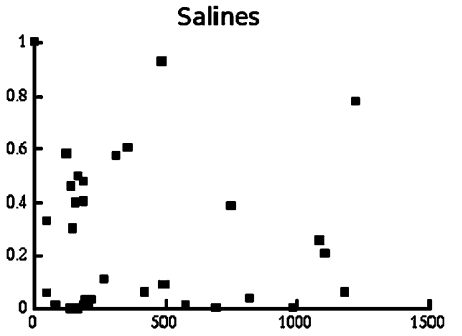

Total numbers in the estuary

Figure 2. Example of the type of relationship between the total population of a target species (Dunlin) present in the estuary and salines combined and the percentage of birds in each of the main intertidal areas and the salines at low-water. Data are for the periods of July to early December of 1993-1995 and 19962000 (low-water).

the low tide in any of the three mudflat areas. For Kentish Plover and Ringed Plover, the proportion (arcsin-transformed) of birds in each intertidal area and in the salines at low-water, did not decrease significantly as total numbers in the estuary increased (for 'Gala' 'Armazéns','Pranto' and salines, respectively: Kentish Plover: $r^{2}=0.0007$, $r^{2}=-0.02, r^{2}=0.02$ and $r^{2}=0.09, n=32, \mathrm{~ns} ;$ 

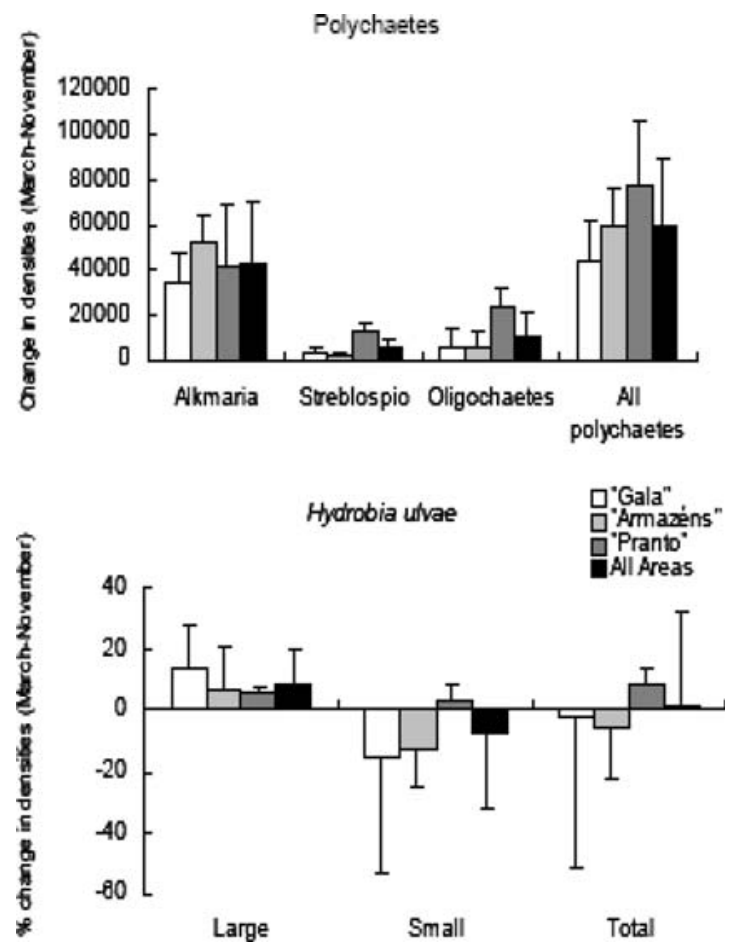

Figure 3. Change in numbers (average of the transects), from November 1993 to March 1994, in the densities of several groups of polychaetes and oligochaetes (above) and percentage changes of different size-classes of Hydrobia ulvae (below) in three main areas of mudflats, and all areas combined, in the Mondego estuary.

Ringed Plover: $r^{2}=0.08, r^{2}=-0.09, r^{2}=-0.02$ and $r^{2}=-0.009, n=32$, ns). The proportion of Dunlin even increased in one area ('Armazéns', $r^{2}=0.19, n=32, p<0.008$ ), but showed no significant trend in the other two and in the salines $\left(r^{2}=-0.03, \mathrm{r}^{2}=-0.0002\right.$ and $r^{2}=-0.03, n=32$, ns; for 'Gala ', 'Pranto' and salines, respectively). The data for Dunlin are shown in Figure 2 to illustrate the distribution of the data points in these analyses.

There was no evidence, either, that the proportion of birds in the salines over high-water decreased with total numbers, for any species $r^{2}=0.25$, $r^{2}=-0.14, r^{2}=0.31, n=12$, ns; for Ringed Plover, Kentish Plover and Dunlin, respectively).

\section{Depletion}

\section{Overwinter reduction in prey abundance}

There was no evidence of an overwinter reduction in the densities of polychaetes and oligochaetes between November and March, as would be expected if waders exerted a strong predation pressure on their food supply (Fig. 3, top). Indeed, the abundance of the individual species or groups of worms, singly and in combination, showed a pronounced increase from November to March (Kruskal-Wallis test: $\chi_{2.33}^{2}=17.03, p<0.001$, $\chi_{2.33}^{2}=12.89, p<0.003, \chi_{2.33}^{2}=13.34, p<0.003$ and $\chi_{2.33}^{2}=18.61, p<0.0001$ for Alkmaria sp., Streblospio sp., Oligochaetes and total Polichaetes, respectively). Significant spatial differences in the magnitude of the increase only occurred in Streblospio and Oligochaetes, which exhibited higher between-month differences in the 'Pranto' area, as compared to the two downstream areas $\left(\chi_{2.16}^{2}=11.49, \quad p<0.003\right.$, and $\chi_{2.16}^{2}=8.72$, $p<0.01$, for the two groups, respectively).

The small decrease in the abundance of all sizeclasses of Hydrobia combined that was observed across all areas was not statistically significant $\left(\chi_{2.32}^{2}=0.006\right.$, ns) (Fig. 3, bottom). However, the seasonal changes in abundance differed between size-classes. The density of the larger individuals across all areas significantly increased from November to March $\left(\chi_{2.32}^{2}=7.07 p<0.008\right)$ whereas the density of the smaller ones did not change $\left(\chi_{2.32}^{2}=0.57, \mathrm{~ns}\right)$. There were no significant differences between the three areas in densities, both for each size class separately $\left(\chi_{2.16}^{2}=3.05\right.$, ns and $\chi_{2.16}^{2}=3.31$, ns, for larger and small Hydrobia, respectively) and for all sizeclasses combined $\left(\chi_{2.16}^{2}=2.92, \mathrm{~ns}\right)$.

\section{Energy requirements of the birds}

The comparison of the birds' energy requirements with the biomass (in $\mathrm{kJ} \mathrm{m}^{-2}$ ) standing stock of the main prey species present in each month from November 1993 to March 1994 is shown in Tables 2 and 3 . The comparison was made on a monthly basis, rather than for the winter as a whole, because of the evidence that food abundance often increased during the winter. Birds removed each month only $0.77-3.41 \%$ of the total gross biomass that was present in that month.

The low values of biomass removed may have been due to the overwhelming predominance of Hydrobia in the macro-invertebrate biomass (Table 1). If the most preferred prey were actually polychaetes, the impact of shorebirds on their food supplies each month would have been greater 
(2.26-13.42\%) (Table 3). If, on the other hand, Hydrobia was the most important prey, as suggested by Lopes et al. (1998) and Cabral et al. (1999), some $37 \%$ of the total and renewing biomass would have been removed by birds during the whole winter. However, given Hydrobia's thick and indigestible shell (Zwarts \& Blomert, 1990), this might be less likely.

\section{Discussion}

Some studies that have attempted to predict the consequences of habitat loss for waders in their wintering or staging sites have focussed on food depletion and paid rather little attention to interference competition (e.g., Evans et al., 1979; Meire et al., 1994). However, competition in the feeding areas may arise from both these feed-back processes (Goss-Custard, 1980) and detailed studies may be required to establish the relative importance of each (Goss-Custard et al., 2001; GossCustard et al., 2003). An attempt was made to assess the occurrence of both processes in the Mondego estuary.

Neither the studies of the distribution of birds over the intertidal feeding areas and salines at low tide nor of the proportion of birds using the salines over high tide provided any evidence that interference competition occurred. If it did occur, its effects must have been operating at such a low level that it did not significantly affect the intake rates and behaviour of the birds. This conclusion is further supported by the lack of a relationship between bird density and pecking rates - which in charadrids are roughly correlated (Pienkowski, 1982) - that was found in a previous study in the Mondego estuary by Cabral et al. (1999). Indeed, in Kentish Plover, the pecking rate even increased with increasing density (Cabral et al., 1999). Further evidence that interference competition was slight or absent in the Mondego intertidal areas is that the density of none of the three species reached the threshold values of 50-300 birds/ha at which, in waders, interference begins to occur (Yates et al., 1999; Triplet et al., 2000; Stillman et al., 2002). During this study, the maximum density recorded in any species barely reached 10 birds/ha (Dunlin, in December 1993). However, the birds were, at any one time, aggregated into only a small part of the area, so their effective density may have exceeded the threshold densities. For birds taking small prey, the interference threshold density would be in the range 150-300 birds ha, possibly more (Stillman et al., 2002). So, for the effective bird density to exceed this threshold, birds would have had to occupy at any one time less that $1 / 15$ th of the whole area (Stillman et al., 2002). In fact, for all studied species, the birds were much more spread out than this

Table 3. Total biomass taken in each month of the winter by all species of waders in the estuary of Mondego during the winter of 1993-1994, in relation to the standing crop biomass (in energy equivalents, $\mathrm{kJ} \mathrm{m}^{-2}$ ) present in each month of (a) all invertebrate species that can potentially be eaten, (b) all invertebrate species excluding Hydrobia ulvae and (c) only Hydrobia ulvae

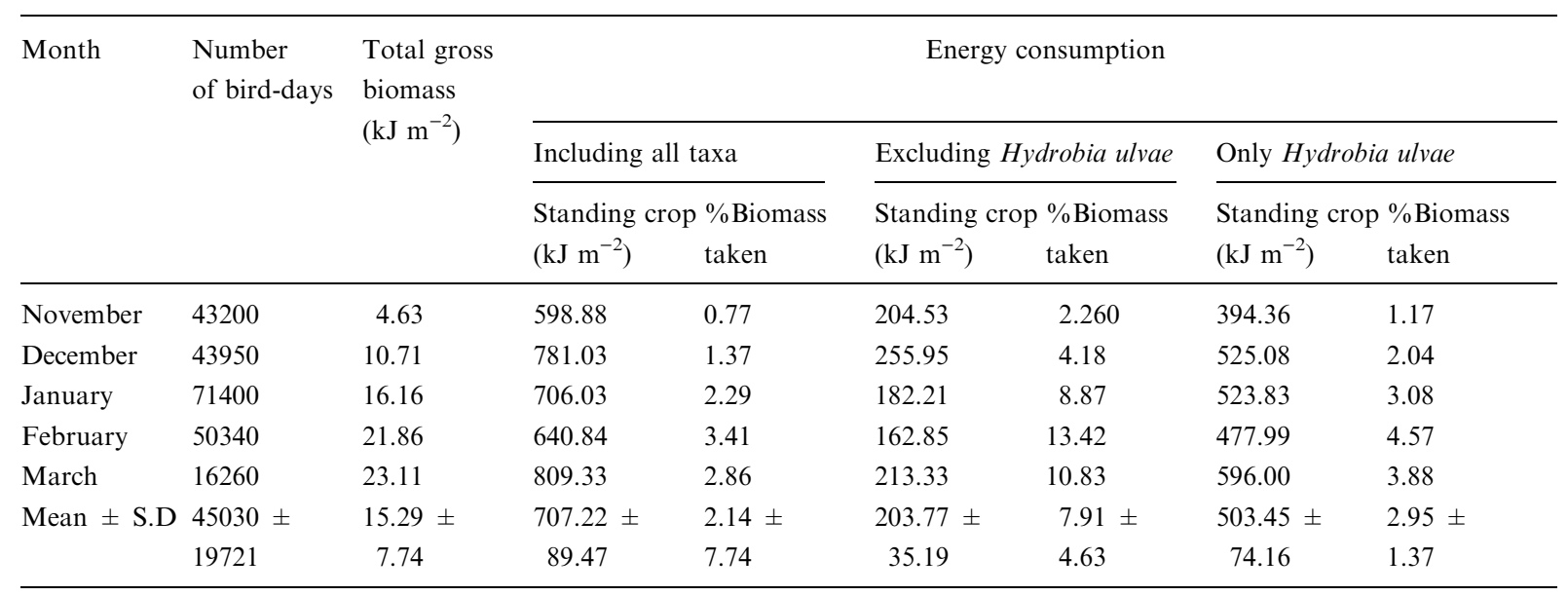

The average values ( \pm 1 standard-deviation of the mean) for the whole period are also given. 
over their feeding areas throughout the whole of the low-water period. Significant aggregation only occurred $1-2 \mathrm{~h}$ before high-water, by which time many birds had already left the interidal areas for their supratidal refuges and most of those remaining had stopped feeding. So, even under these circumstances, it is very unlikely that bird density was high enough for the effective density threshold to be reached. There is therefore little reason to suspect that interference would have affected the intake rates of most waders.

Depletion of the main food supplies of waders in intertidal areas also seems to have been negligible. Indeed, the densities of the probably most important prey types, small polychaete worms and larger Hydrobia, actually increased from November to March, despite the depletion by birds. This was presumably due to over-winter growth and/or reproduction of the invertebrates in this warmtemperate latitude estuary, in contrast to its northern counterparts. Pardal (1998) found that the polychaete Alkmaria romijni showed continuous growth throughout the winter. As for Hydrobia, the decrease in small-sized Hydrobia, and corresponding increase in the number of large-sized ones, suggests that growth also occurred in this species in the Mondego estuary over the winter.

The conclusion that overwinter prey depletion was negligible was reinforced by the comparison between the birds' energy requirements and the standing stocks of the prey. Biomass consumption by birds was very small, being generally less than $8 \%$ over the whole winter, even when Hydrobia, the dominant species in the flats, was excluded. This value is well below the typical values reviewed by Goss-Custard (1980) for north temperate estuaries $(22-45 \%)$, except in the highly improbable case that Hydrobia constituted the bulk of the diet for all species.

A recent study using exclosures to assess the impact of bird predation and the presence of algal mats on the abundance of intertidal invertebrates confirmed that predation by birds was a negligible factor in reducing prey abundances in this estuary (Lopes et al., 2000). As Lopes et al.,'s study was conducted during the spring migration period of the birds, and lasted for just 2 months, their results cannot be directly compared to ours, but does further indicatate that prey depletion by birds is probably small in the Mondego estuary.
In summary, the data indicate that competition through interference and depletion on the mudflats of the Mondego estuary was probably weak, or entirely absent, during the study period. As a consequence, the mudflats are likely to be able to accommodate more birds over low tide. However further research, probably involving individuals behaviour-based modelling (Goss-Custard et al., 2002), would be required to predict when food competition would intensify to the point at which some birds would die or leave the estuary.

This conclusion should not be taken to suggest, however, that birds would be able to continue to feed as well as they do at present were the salinas to be reduced. Despite the fact that no evidence of interference competition was found to occur in this habitat at present, the salines are known to provide both alternative and supplementary feeding for the estuarine birds (Múrias et al., 2002). Low levels of competition on the mudflats does not necessarily mean, therefore, that removing the salinas would not make it more difficult for some birds to obtain their daily requirements, especially as their removal would reduce the time available for foraging from 12 to $8 \mathrm{~h}$. Thus, the loss of salines in the Mondego estuary may not be neutral in terms of its effects on wintering birds even though competition on the main intertidal feeding grounds does seem to be weak or absent at the moment. The next step is to model the system so that the combined effect of the loss of important salines feeding areas and the loss of feeding time on bird fitness can be predicted (Goss-Custard et al., 2002).

\section{Acknowledgments}

This work was supported by the Portuguese Research Board (FCT), through grants FMRH/BD/ 331/93 and PRAXIS XXI/BD/5570/95 (TM), PRAXIS XXI BM/3261/92-IG (JAC) and PRAXIS XXI BM/7232/95 (RL). The authors are indebted to all colleagues that helped in the fieldwork.

\section{References}

Cabral, J. A., M. A. Pardal, R. Lopes, T. Múrias \& J. C. Marques, 1999. The impact of macroalgal blooms on the use 
of the intertidal area and feeding behaviour of waders (Charadrii) in the Mondego estuary (west Portugal). Acta Oecologica 20: 417-427.

Cardoso, P. G., A. I. Lillebø, M. A. Pardal, S. M. Ferreira \& J. C. Marques 2002. The effect of different primary producers on Hydrobia ulvae population dynamics: a case study in a temperate intertidal estuary. Journal of Experimental Marine Biology and Exology 277: 173-195.

Cardoso, P. G., M. A. Pardal, A. I. Lillebø, S. M. Ferreira, D. Raffaelli \& J. C. Marques, 2004. Dynamic changes in seagrass assemblages under eutrophication and implications for recovery. Journal of Experimental Marine Biology (in press).

Cramp, S. \& K. Simmons, 1983. The birds of Western Paleartic, Vol. III, Waders to Gulls. Oxford University Press, Oxford.

Cunha, P. P. \& J. Dinis, 2002. Sedimentary dynamics of the Mondego estuary. In Pardal, M. A., M. A. Graça \& J. C. Marques (eds), Aquatic Ecology of the Mondego River Basin. Global Importance of Local Experience Impeensa da Universidade de Coimbra. Coimbra.

Davidson, N. \& P. Rothwell, 1993. Disturbance to waterfowl on estuaries. Wader Study Group Bulletin 68 (Special Issue): $1-106$.

Dolbeth, M, M. A, Pardal, A. I. Lillebø, U. Azeiteiro \& J. C, Marques, 2003. Short- and long-term effects of eutrophication on the secondary production of an intertidal macrobenthic community. Marine Biology 143(6): 1229-1238.

Evans, P. R., D. M. Herdson, P. J. Knights \& M. W. Pienkowski, 1979. Short-term effects of reclamation of part of Seal Sands, Teesmouth, on wintering waders and Shelduck. I. Shorebird diets, invertebrate densities, and the impact of predation on the invertebrates. Oecologia (Berl.) 41: 183206.

Goss-Custard, J. D. \& A. D. West, 1997. The concept of carrying capacity and shorebirds in effect of habitat loss and changes on waterbirds. In Goss-Custard, J. D., A. Luís \& R. Rufino (eds), ITE Symposium 30/Wetlands International publication $42 \mathrm{CEH} / \mathrm{NERC}$. London: 52-62.

Goss-Custard, J. D. \& S. E. A. Durrell, 1990. Bird behaviour and environmental planning: approaches in the study of wader populations. Ibis 132: 273-289.

Goss-Custard J. D., S. E. A. le V. dit Durrel, S. McGrorty \& R. C. Reading, 1982. Use of Mussel Mytilus edulis by Oystercatcher Haematopus ostralegus according to age and population size. Journal of Animal Ecology 51: 543-554.

Goss-Custard, J. A., R. M. Warwick, R. Kirby, S. McGrorty, R. T. Clarke, B. Pearson, W. E. Rispin, S. E. A. le V. dit Durrel \& R. J. Rose, 1991. Towards predicting wading bird densities from prey densities in a post-barrage Severn estuary. Journal of Applied Ecology 28: 1004-1026.

Goss-Custard, J. D., A. D. West, R. T. Clarke, R. W. Caldow \& S. E. A. le V. dit Durrel, 1996. The carrying capacity of coastal habitats for Oystercatchers. In Goss-Custard, J. D. (ed), The Oystercatcher. From Individuals to Populations. Oxford University Press. Oxford: 352-381.

Goss-Custard, J. D., A. D. West, R. A. Stilmann, S. E. A. le V. dit Durrel, R. W. J. Caldow, S. McGrorty \& R. Nagarajan, 2001. Density-dependent starvation in a vertebrate without significant depletion. Journal of Animal Ecology 70: 955-965.
Goss-Custard, J. D., R. A. Stilmann, A. D. West, R. W. J. Caldow \& S. McGrorty, 2002. Carrying capacity in overwintering migratory birds. Biological Conservation 105: $27-$ 41.

Goss-Custard, J. D., R. A. Stillman, R. W. G. Caldow, A. D. West \& M. Guillemain, 2003. Carrying capacity in overwintering birds: when are spatial models needed? Journal of Applied Ecology 40: 176-187.

Goss-Custard, J. D., 1980. Competition for food and interference among waders. Ardea 68: 31-52.

Goss-Custard, J. D., 1984. Intake rate and food supply in migrating and overwintering shorebirds. In Burger, J. \& Olla, (eds.), Behaviour of Marine Animals. shorebirds, migration and foraging behaviour Vol. VI, Plenum Press, New York: 233-270.

Klaassen, M., M. Kersten \& B. Ens, 1990. Energetic requirements for maintenance and premigratory body mass gain of waders wintering in Africa. Ardea 78: 209-220.

Lopes, R., J. A. Cabral, T. Múrias \& J. C. Marques, 1998. Contribuição para o conhecimento da dieta do Pilrito-comum Calidris alpina e da Tarambola-cinzenta Pluvialis squatarola no estuário do Mondego. Airo 9: 28-33.

Lopes, R., M. A. Pardal \& J. C. Marques, 2000. Impact of macroalgal blooms and wader predation on intertidal macroinvertebrates: experimental evidence from the Mondego estuary (Portugal). Journal of Experimental Marine Biology and Ecology 249: 165-179.

Lopes, R., J. A. Cabral, T. Múrias, C. Pacheco \& J. C. Marques 2001. Status and habitat use of waders in the Mondego estuary. In Pardal, M. A., J. C. Marques \& M. A. Graça (eds), Aquatic Ecology of the Mondego River Basin: Global Importance of Local Experience. Imprensa da Universidade de Coimbra, Coimbra: 219-230.

Luís, A., 1999. Influência de factores naturais e humanos nas limícolas (Aves, Charadrii) invernantes na Ria de Aveiro, com especial referência ao Pilrito-comum (Calidris alpina). $\mathrm{PhD}$ Thesis, University of Aveiro.

McLusky, D. S., 1989. Ecology of Estuaries. Heinemann Educational Books, Ltd. London.

Meire, P. M., H. Schekkermman \& P. Meininger, 1994. Consumption of benthic invertebrates by waterbirds in the Oosterschelde estuary, SW Netherlands. Hydrobiologia 282/ 283: 525-546.

Moreira, F., 1994a. Diet and feeding rates of Knots Calidris canutus in the Tagus estuary (Portugal). Ardea 82: 133-136.

Moreira, F., 1994b. Diet, prey selection and intake rates of Black-tailed Godwits Limosa limosa feeding on mudflats. Ibis 136: 249-355.

Moreira, F., 1995. The winter feeding ecology of Avocets Recurvirostra avosetta on intertidal areas. II. Diet and feeding mechanisms. Ibis 137: 99-108.

Múrias, T., 1997. Effects of Habitat Loss on Waders (Aves, Charadrii) in the Mondego estuary (Portugal). PhD Thesis. University of Coimbra.

Múrias, T., J. A. Cabral, R. Lopes, J. C. Marques \& J. D. GossCustard, 2002. Use of traditional salines by waders in the Mondego estuary (Portugal): a conservation perspective. Ardeola 49: 223-240. 
Múrias, T., J. A. Cabral, R. Lopes \& J. C. Marques, 1997. Lowwater use of the mondego estuary (West Portugal) by waders. Ardeola 44: 79-91.

Nagy, K. A., I. A. Gerard \& T. K. Brown 1999. Energetics of free-ranging mammals, reptiles, and birds. Annual Revue of Nutrition: 247-277.

Pardal, M. A. 1998. Impacto da eutrofização nas comunidades macrobentónicas do braço sul do estuário do Mondego (Portugal). PhD Thesis. University of Coimbra.

Pienkowski, M. W. 1982. Diet and energy intake of Grey and Ringed Plovers Pluvialis squatarola and Charadrius hiaticula, in the nonbreeding season. Journal of Zoology (London) 197: 511-549.

Rufino, R. A. Araújo, J. P. Pina \& P. S. Miranda 1984. The use of salines by waders in the Algarve, South Portugal. Wader Study Group Bulletin 42: 41-42.

Rufino, R. \& R. Neves, 1992. The effect on wader populations of the conversion of salinas into fishfarms IWRB Special Publication 20: 177-182.

Smit, C. J., R. H. D. Lambeck \& W. J. Wolff, 1987. Threats to coastal wintering and staging areas of waders. In Davidson N. C. \& M. W. Pienkowski, (eds.), The Conservation of International Flyway Populations of Waders 105-113. Wader Study Group Bulletin 49/IWRB Special Publication 7.
Stillman, R. A., A. E. Poole, J. D. Goss-Custard, R. W. G Caldow, M. G. Yates, \& P. Triplet, (2002) Predicting the strength of interference more quickly using behaviour-based models. Journal of Animal Ecology 71: 532-541.

Schekkerman, H., P. L. Meininger \& P. M. Meire, 1994. Changes in waterbird populations of the Oosterchelde (SW Netherlands) as a result of large-scale coastal engenieering works. Hydrobiologia 282/283: 509-524.

Triplet, P., R. Stillman \& J. D. Goss-Custard, 2000. Prey abundance and the strength of interference in a foraging shorebird. Journal of Animal Ecology 68: 254-265.

Yates, M. G., R. A. Stillman \& J. D. Goss-Custard, 1999. Contrasting interference functions and foraging dispersion in two species of shorebird (Charadrii). Journal of Animal Ecology 63: 314-322.

Zwarts, L. \& A. M. Blomert, 1990. Selectivity of Whimbrels feeding of Fiddler Crabs explained by component specific digestibilities. Ardea 78: 339-364.

Zwarts, L. \& J. H. Wanink, 1993. How the food supply harvestable by waders in the Wadden Sea depends on the variation in energy density, body weight, biomass, burying depth and behaviour of tidal-flat invertebrates. Netherlands Journal of Sea Research 31: 441-476. 